\title{
Fattening bulls on maize silage and concentrate supplemented with vegetable oils
}

\section{J. Strzetelski ${ }^{1}$, J. Kowalczyk ${ }^{2}$, S. Osięglowski ${ }^{3}$, T. Stasiniewicz ${ }^{1}$, E. Lipiarska ${ }^{1}$ and H. Pustkowiak ${ }^{4}$}

\author{
'Research Institute of Animal Production, Department of Animal Nutrition \\ 32-083 Balice, Poland \\ 'The Kielanowski Institute of Animal Physiology and Nutrition, Polish Academy of Sciences \\ 05-110 Jablonna, Poland \\ ${ }^{3}$ Research Institute of Animal Production, Experimental Station \\ 64-122 Pawlowice, Poland \\ ${ }^{4}$ The Agricultural University of Cracow, Department of Animal Breeding \\ Al. Mickiewicza 24/28, 30-059 Kraków, Poland
}

(Received 9 March 2001; accepted 20 April 2001)

\section{ABSTRACT}

An experiment was carried out on 44 Black-and-White Lowland bulls allocated to 4 groups and fattencd from 184 to $530 \mathrm{~kg}$ average body weight to investigate animal performance and meat quality when fed diets with balanced energy:protein ratio according to the INRA system. Dicts consisted of maize silage and concentrate for the control group, supplemented with linseed, rapeseed oil cake, rape seed oil as additional fat sources for the experimental groups. Six animals from each group were slaughtered at the end of the experiment. The physical and chemical properties of meat, and its individual fatty acid and cholesterol contents were estimated. Average body weight gains of animals were similar in all groups reaching about $1.35 \mathrm{~kg} \mathrm{day}^{-1}$. The fat content increased to about $5 \%$ in dry matter with about $50 \%$ fat from linseed or rapeseed oil cake, enriched the lipids of $M$. longissimus dorsi in essential and unsaturated fatty acids, conjugated linoleic acid and decreased the cholesterol level, which was particularly marked when feeding the dict supplemented with rapeseed oif cake. The highest ratio of hypocholesterolemic to hypercholesterolemic acids was also found in the meat of animals fed diet with rapeseed oil cake.

KEY WORDS: bulls, fattening, vegetable oils, fat composition, fatty acids, meat properties 


\section{INTRODUCTION}

The combination of maize silage with concentrate appears to be one of the most effective diets for fattening bulls, but their meat contains fat with a high ratio of saturated (SFA) to unsaturated (UFA) acids (Scollan et al., 1997; Givens et al., 2000). The fatty acid profile of meat fat can be modified by supplementing diets for ruminants with vegetable or fish oils, with biohydrogenation in the rumen being an important factor influencing changes in fatty acid profiles in meat tissue or milk fat (Kennelly, 1996; Stasiniewicz et al., 2000). Deposition of fatty acids in beef fat has become of interest during recent decades since it is now considered that polyunsaturated fatty acids, particularly of the n-3 family, in the diet for humans can prevent numerous disorders such as heart disease (Sheard, 1998), promote brain development and visual acuity in infants (Hoffmann et al., 1993), modulate autoimmunity (Calder, 1997; Grimble, 1998) and inflammatory disorders (Simopoulos, 1991). They are also believed to be involved in the pathophysiology of major depression (Maes, 1999).

The aim of the present study was to assess the effect of feeding fattening bulls with maize silage and concentrate diets supplemented with rape seed oil, rapeseed oil cake or linseed on bulls performance, meat quality, fatty acid proportions and cholesterol level in deposited meat tissue fat.

\section{MATERIAL AND METHODS}

\section{Animals and feeding}

The experiment was carried out on 44 Black-and-White Lowland bulls with an average $72 \%$ (50.0 to 87.5$) \mathrm{HF}$ blood share and average initial weight of $184 \pm 40$ $\mathrm{kg}$ fattened to $530 \pm 10 \mathrm{~kg}$ final body weight. The animals were divided into four groups of 11 according to an analogue method taking into account initial body weight and HF blood share. Initial and final body weights were determined as mean weights before morning feeding for two successive days. The animals were kept in individual stalls equipped with an automatic drinking bowls and a slatted floor lined with rubber matting.

The bulls were given diets containing silage of whole maize plant, pelleted concentrate mixture $(\phi=8 \mathrm{~mm})$ and rapeseed oilmeal as a high-protein supplement. This was the basal diet for control group $\mathrm{C}$, and was supplemented with different sources of fat in the experimental groups: ground linseed - group L, rapeseed oil cake - group RC or rape seed oil - group RO. The energy and protein value of feeds, components of concentrate mixtures (Table 1) and daily rations were established according to IZ-INRA (1997) feeding standards using WINWAR 
Ingredient composition of concentrate mixtures, $\%$

\begin{tabular}{|c|c|c|c|c|}
\hline \multirow{2}{*}{ Feed components } & \multicolumn{4}{|c|}{ Concentrate mixtures } \\
\hline & $\mathrm{C}^{\prime}$ & $L^{\prime}$ & $\mathrm{RC}^{\prime}$ & $\mathrm{RO}^{\prime}$ \\
\hline Triticale & 57.5 & 62.5 & 56.0 & 54.7 \\
\hline Wheat bran & 24.5 & 4.5 & 10.5 & 23.3 \\
\hline Soyabean oilmeal & 15.0 & 11.0 & 1.5 & 14.3 \\
\hline Linseed ground & - & 19.0 & - & - \\
\hline Rapeseed oil cake & - & - & 29.0 & - \\
\hline Rape seed oil & - & - & - & 4.8 \\
\hline Mineral mixture ${ }^{2}$ & 0.6 & 0.6 & 0.6 & 0.6 \\
\hline Binder & 0.5 & 0.5 & 0.5 & 0.5 \\
\hline Limestone & 1.9 & 1.9 & 1.9 & 1.8 \\
\hline
\end{tabular}

' $\mathrm{C}$ - control; $\mathrm{L}$ - with ground linseed; $\mathrm{RC}$ - with rape secd oil cake; $\mathrm{RO}$ - with rape seed oil

'contained, g kg-1: $102 \mathrm{P}, 165 \mathrm{Ca}, 46 \mathrm{Mg}, 92 \mathrm{Na}$; mg/kg: $122.5 \mathrm{Cu}, 315 \mathrm{Zn}, 1075 \mathrm{Fe}, 8.0 \mathrm{Co}, 810 \mathrm{Mn}$

ver. $1.6(2000)$, WINMIX ver. 1.7 (2000) and INRAtion ver. 2.63 (1998/99) software. Concentrate mixtures for experimental groups were formulated to include increased fat content but similar level of cereals, crude protein, PDI and UFV as in control diet.

Pellets of concentrate mixtures were produced using Type H-710 RofamaRogoźno (Poland) equipment after treatment at $185^{\circ} \mathrm{C}$ and $6 \mathrm{~atm}$. for $1 \mathrm{sec}$. with steam. Pellet bathes were stored for no longer than 3 months.

Daily rations were established for each $30 \mathrm{~kg}$ body weight gain compartment and changed every $30 \pm 2$ days. The feeding schedule was intended to contain from 2.5 to $4.5 \mathrm{~kg}$ of concentrate mixture in the daily ration and from 7 to $18 \mathrm{~kg}$ of maize silage, but in practice the animals received silage ad libitum. Rapeseed oilmeal (from 0.4 to $0.5 \mathrm{~kg} \mathrm{day}^{\prime}$ ) and concentrate mixture were given once daily to a separate box in the crib. Rapeseed oilmeal was offered only until the animals reached $450 \mathrm{~kg}$ body weight.

Sampling and analysis

At the end of the fattening period 6 bulls of each group were chosen at random, slaughtered and meat samples of $M$. longissimus dorsi were taken for fatty acids analysis in extracted fat by gas chromatography on Pye Unicam GC104 equipment using a $30 \mathrm{~m}$ long Supelcowax 10 column $(\mathrm{f}=0.53 \mathrm{~mm})$, and cholesterol estimation on Pye Unicam GC106 using a $30 \mathrm{~m}$ long ( $\mathrm{f}=0.53 \mathrm{~mm}$ ) HP5 column. The physical and chemical properties of meat were estimated as described by Strzetelski et al. (1998). Nutrient content in feeds was determined according to AOAC (1990) methods. 
The results were subjected to statistical analysis using one way analysis of variance according to Statgraphics Plus ver. 6.0 (1992).

\section{RESULTS}

The crude fat content in experimental feed mixtures was from 2.5- in group $\mathrm{RC}$ to 3.3-fold more in group $\mathrm{L}$ than in the unsupplemented control mixture (Table 2). Daily crude fat intake in groups averaged $(\mathrm{g}): \mathrm{C}-200.4 ; \mathrm{L}-372.4 ; \mathrm{RC}-313.4$ and $\mathrm{RO}-365.3$, and oil supplement representing $0,56.8,45.8$ and $44.1 \%$, respectively, of total fat in the mixtures. The content of fat in dry matter of the whole ration of the respective groups was $2.7,5.2,4.3$ and $4.8 \%$. The concentrate mixture with rapeseed oil cake contained the highest level of crude protein and the lowest level of energy (UFV) and protein digestible in the intestine (PDI).

Daily intake of silage, concentrate, dry matter and PDIN did not differ among the groups. Crude protein intake in group $R C$ was higher than in group $L(P<0.05)$. Average maize silage intake during the experimental period was, as planned in the schedule of experiment, about $12 \mathrm{~kg} \mathrm{day}^{-1}$ (Table 3). Diets for groups $\mathrm{C}$ and RO contained more PDIE than PDIN but this difference was small and after recalculation for UFV amounted to $+2.3 \mathrm{~g} \mathrm{UFV}^{-1}$. In groups $\mathrm{L}$ and RC, PDIN exceeded PDIE and differences expressed as (PDIE - PDIN)/UFV were $-1.4 \mathrm{~g}$ and $-7.6 \mathrm{~g}$ $\mathrm{UFV}^{-1}$, respectively for groups. Intake of PDIE in groups $\mathrm{C}$ and $\mathrm{RO}$ was greater than in groups $\mathrm{L}$ and $\mathrm{RC}(\mathrm{P}<0.01$ or 0.05$)$. Energy intake (UFV) was slightly greater in groups $\mathrm{L}$ and $\mathrm{RO}$ than in other two groups, significant differences were found between group $\mathrm{RC}$ in relation to groups $\mathrm{L}$ and $\mathrm{RO}(\mathrm{P}<0.01)$.

Daily body weight gain was assumed to $1300 \mathrm{~g}_{\text {day }}{ }^{-1}$. This value was quite close to obtained in all groups and amounted about $1348 \pm 13$ g day $^{-1}$ (Table 4), but in the range of body weight from 350 to $450 \mathrm{~kg}$ daily gains were from 1400 to $1580 \mathrm{~g}^{-1} \mathrm{y}^{-1}$ (Figure 1) in accordance with energy content (UFV) of consumed feeds. The growth rate of fattening bulls in all groups was similar and linear during the fattening period (Figure 2). Complete feed, dry matter and nutrients efficiency did not differ between the groups, but a significant difference was found in UFV efficiency as groups $\mathrm{RC}$ and $\mathrm{C}$ utilized energy better than group $\mathrm{RO}(\mathrm{P}<0.05)$.

Total SFA, particularly of C 14:0; C 15:0 and C 16:0, content in the lipids of $M$. longissimus dorsi of animals fed rations with $\mathrm{RC}$ was lower than on the other diets $(\mathrm{P}<0.05)$ leading to a pronounced increase of the UFA: SFA ratio $(\mathrm{P}<0.01)$. At the same time, the content of polyunsaturated fatty acids of the n- 6 family with 18,20 and 22 carbon atoms in the molecule was higher in this fat but this difference was not always significant (Table 5). The proportion of hypocholesterolemic to hypercholesterolemic acids in the meat of animals from group $\mathrm{RC}$ was higher than in the remaining groups $(\mathrm{P}<0.01)$. The content of SFA, UFA and UFA:SFA ratio in fat of 
Nutrient contents in feeds used in experiment, in $1 \mathrm{~kg}$ of feed

\begin{tabular}{|c|c|c|c|c|c|c|c|c|}
\hline Feed & $\begin{array}{c}\text { Dry matter } \\
\mathrm{g}\end{array}$ & $\begin{array}{c}\text { Crude protein } \\
\mathrm{g}\end{array}$ & $\begin{array}{c}\text { Ether extract } \\
\mathrm{g}\end{array}$ & $\begin{array}{c}\text { Crude fibre } \\
\mathrm{g}\end{array}$ & $\begin{array}{c}\text { Ash } \\
\mathrm{g}\end{array}$ & UFV & $\begin{array}{c}\text { PDIN } \\
\mathrm{g}\end{array}$ & $\begin{array}{c}\text { PDIE } \\
\mathrm{g}\end{array}$ \\
\hline Maize silage & 347 & 29 & 9.8 & 74.7 & 18.9 & 0.28 & 18 & 23 \\
\hline Rapeseed oilmeal & 885 & 345 & 23.1 & 130.7 & 66.1 & 0.94 & 222 & 139 \\
\hline Rapeseed oil cake & 894 & 325 & 148 & 137.7 & 62 & 0.69 & 200 & 89 \\
\hline Lineseed ground & 916 & 218 & 331 & 101 & 38 & 1.32 & 127 & 60 \\
\hline Rape seed oil & 992 & - & 980 & - & 15 & 2.80 & - & - \\
\hline \multicolumn{9}{|l|}{ Feed mixtures } \\
\hline $\mathrm{C}^{1}$ & 881 & 164 & 23 & 44 & 30 & 0.98 & 113 & 107 \\
\hline$L^{1}$ & 888 & 165 & 75 & 45 & 28 & 1.09 & 110 & 97 \\
\hline $\mathrm{RC}^{1}$ & 884 & 178 & 58 & 63 & 34 & 0.92 & 116 & 91 \\
\hline $\mathrm{RO}^{\prime}$ & 886 & 156 & 70 & 42 & 29 & 1.05 & 107 & 101 \\
\hline
\end{tabular}

${ }^{1} \mathrm{C}$ - control; $\mathrm{L}$ - with linseed; $\mathrm{RC}$ - with rapeseed oil cake; $\mathrm{RO}$ - with rape seed oil 
TABLE 3

Daily intake of feeds and nutrients

\begin{tabular}{|c|c|c|c|c|c|}
\hline \multirow{2}{*}{ Feed and nutrient } & \multicolumn{4}{|c|}{ Groups } & \multirow{2}{*}{ SE } \\
\hline & $\mathrm{C}^{1}$ & $\mathrm{~L}^{1}$ & $\mathrm{RC}^{\mathrm{I}}$ & $\mathrm{RO}^{1}$ & \\
\hline Maize silage, $\mathrm{kg}$ & 11.97 & 11.42 & 11.52 & 12.68 & 0.229 \\
\hline Concentrate mixture, $\mathrm{kg}$ & 3.32 & 3.37 & 3.34 & 3.35 & 0.011 \\
\hline Rapeseed oilmeal, kg & 0.29 & 0.28 & 0.30 & 0.30 & 0.03 \\
\hline Dry matter, kg & 7.34 & 7.21 & 7.21 & 7.63 & 0.810 \\
\hline Crude protein, $\mathrm{g}$ & $993^{\mathrm{ab}}$ & $984^{a}$ & $1030^{\mathrm{b}}$ & $991^{\mathrm{ab}}$ & 7.047 \\
\hline PDIN, g & 656 & 639 & 660 & 654 & 4.254 \\
\hline PDIE, $g$ & $672^{\mathrm{Bb}}$ & $629^{\mathrm{ABa}}$ & $610^{\mathrm{Aa}}$ & $671^{\mathrm{Bb}}$ & 6.586 \\
\hline UFV & $6.89^{\mathrm{ABab}}$ & $7.12^{\mathrm{Bbc}}$ & $6.58^{\mathrm{Aa}}$ & $7.34^{\mathrm{Bc}}$ & 0.077 \\
\hline
\end{tabular}

$1 \mathrm{C}$ - control; L - with ground linseed; $\mathrm{RC}$ - with rapeseed oil cake; $\mathrm{RO}$ - with rape seed oil $a, b, c-P<0.05$

$\mathrm{A}, \mathrm{B}-\mathrm{P}<0.01$

$\mathrm{SE}=\sqrt{\frac{\mathrm{S}^{2}}{\mathrm{n}}}$

TABLE 4

Body weight, daily gains and feed utilization

\begin{tabular}{lccccc}
\hline \multirow{2}{*}{ Item } & \multicolumn{4}{c}{ Groups } & \multirow{2}{*}{ SE } \\
\cline { 2 - 5 } & $\mathrm{C}^{1}$ & $\mathrm{~L}^{\mathrm{1}}$ & $\mathrm{RC}^{\mathrm{l}}$ & $\mathrm{RO}^{1}$ & \\
\hline Initial body weight, $\mathrm{kg}$ & 184 & 184 & 184 & 184 & 3.905 \\
Final body weight, kg & 529 & 529 & 528 & 530 & 0.934 \\
Fattening period, days & 253 & 259 & 261 & 256 & 3.986 \\
Body weight gain, gday ${ }^{-1}$ & 1367 & 1342 & 1328 & 1356 & 13.79 \\
& & & & & \\
Feed utilization per 1 kg gain & & & & & \\
Maize silage, kg & 8.76 & 8.53 & 8.70 & 9.38 & 0.230 \\
Concentrate mixture, kg & 2.44 & 2.53 & 2.53 & 2.48 & 0.028 \\
Rapeseed oilmeal, kg & 0.21 & 0.21 & 0.22 & 0.22 & 0.04 \\
Dry matter kg & 5.38 & 5.39 & 5.45 & 5.65 & 0.071 \\
Crude protein, g & 727 & 737 & 779 & 734 & 8.721 \\
PDI, g & 481 & 471 & 461 & 483 & 5.381 \\
UFV & $5.04^{\mathrm{a}}$ & $5.34^{\mathrm{ab}}$ & $4.97^{\mathrm{a}}$ & $5.44^{\mathrm{b}}$ & 0.069 \\
\hline
\end{tabular}

${ }^{1} \mathrm{C}$ - control; $\mathrm{L}$ - with ground linseed; $\mathrm{RC}$ - with rapeseed oil cake; $\mathrm{RO}$ - with rape seed oil a, b $-\mathrm{P}<0.05$

$S E=\sqrt{\frac{S^{2}}{n}}$ 


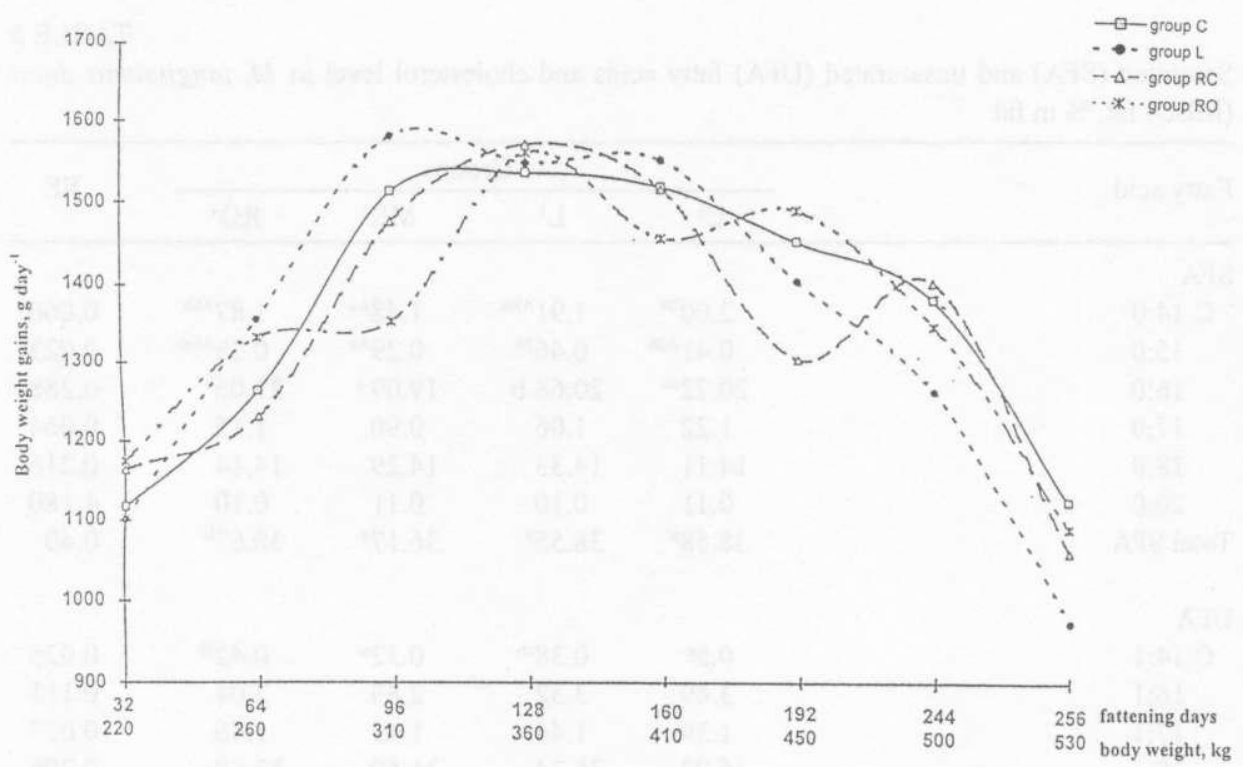

Figure 1. Daily body weight gains in the experimental period

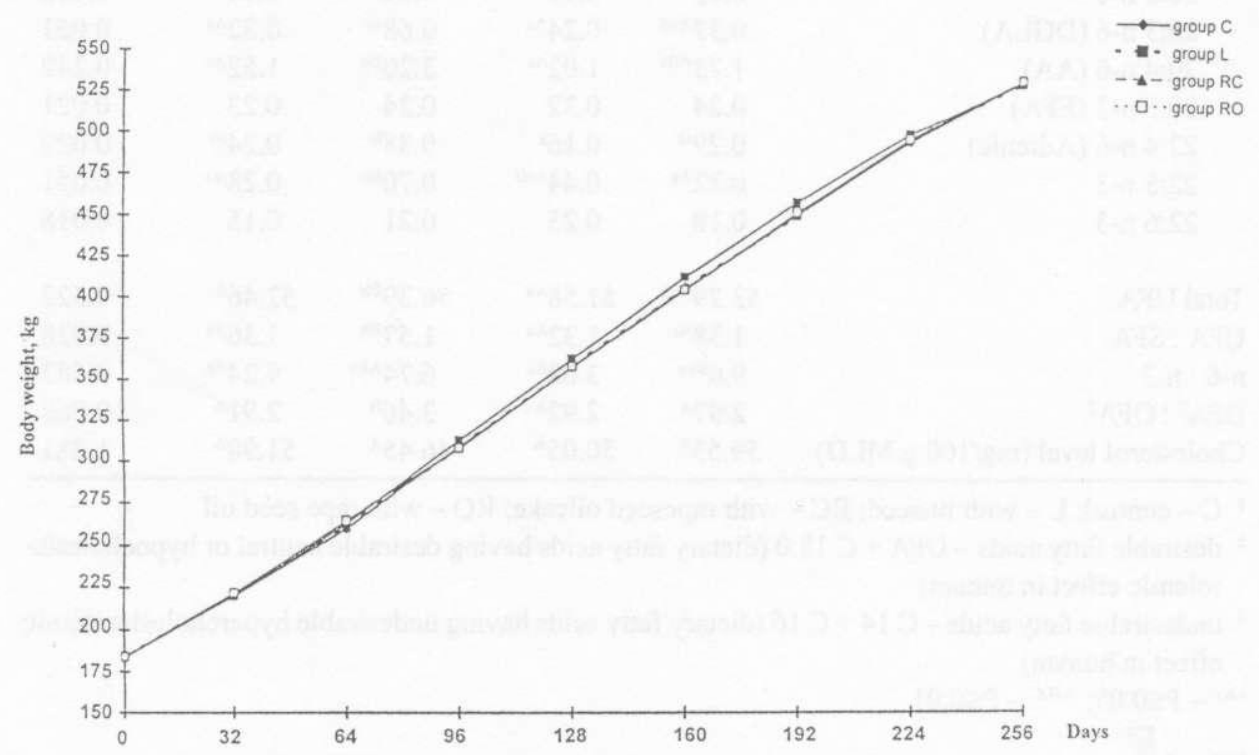

Figure 2. Growth rate of fattening bulls 
TABLE 5

Saturated (SFA) and unsaturated (UFA) fatty acids and cholesterol level in M. longissimus dorsi (MLD) fat, \% in fat

\begin{tabular}{|c|c|c|c|c|c|}
\hline \multirow{2}{*}{ Fatty acid } & \multicolumn{4}{|c|}{ Groups } & \multirow{2}{*}{ SE } \\
\hline & $\mathrm{C}^{1}$ & $\mathrm{~L}^{1}$ & $\mathrm{MR}^{1}$ & $\mathrm{RO}^{1}$ & \\
\hline \multicolumn{6}{|l|}{ SFA } \\
\hline C 14:0 & $2.00^{\mathrm{Bb}}$ & $1.91^{\mathrm{ABb}}$ & $1.48^{\mathrm{Aa}}$ & $1.87^{\mathrm{Abb}}$ & 0.066 \\
\hline $15: 0$ & $0.41^{\mathrm{ABb}}$ & $0.46^{\mathrm{Bb}}$ & $0.29^{\mathrm{Aa}}$ & $0.35^{\text {Abab }}$ & 0.023 \\
\hline $16: 0$ & $20.72^{\mathrm{ab}}$ & $20.68 \mathrm{~b}$ & $19.09^{\mathrm{a}}$ & $21.06^{b}$ & 0.288 \\
\hline $17: 0$ & 1.22 & 1.06 & 0.90 & 1.15 & 0.064 \\
\hline $18: 0$ & 14.11 & 14.33 & 14.29 & 14.14 & 0.216 \\
\hline $20: 0$ & 0.11 & 0.10 & 0.11 & 0.10 & 4.180 \\
\hline Total SFA & $38.58^{b}$ & $38.55^{b}$ & $36.17^{\mathrm{a}}$ & $38.67^{b}$ & 0.40 \\
\hline \multicolumn{6}{|l|}{ UFA } \\
\hline C $14: 1$ & $0.5^{\mathrm{a}}$ & $0.38^{\mathrm{ab}}$ & $0.32^{\mathrm{a}}$ & $0.42^{\mathrm{ab}}$ & 0.025 \\
\hline $16: 1$ & 3.49 & 3.32 & 2.89 & 3.04 & 0.113 \\
\hline $17: 1$ & 1.39 & 1.44 & 1.43 & 1.46 & 0.057 \\
\hline $18: 1$ & 36.92 & 35.74 & 35.69 & 37.69 & 0.706 \\
\hline $18: 2 n-6$ & $6.80^{\mathrm{ab}}$ & $6.28^{a}$ & $9.09^{b}$ & $6.07^{\mathrm{a}}$ & 0.492 \\
\hline $18: 2$ conjugated (CLA) & $0.21^{\mathrm{a}}$ & $0.29^{\mathrm{ab}}$ & $0.31^{\mathrm{b}}$ & $0.20^{a}$ & 0.016 \\
\hline $18: 3$ n-3 ALA & $0.33^{\mathrm{Aa}}$ & $1.28^{\mathrm{ce}}$ & $0.63^{\mathrm{Bb}}$ & $0.27^{\mathrm{Aa}}$ & 0.088 \\
\hline $18: 3 n-6$ & $0.10^{\mathrm{b}}$ & $0.04^{\mathrm{a}}$ & $0.07^{\mathrm{ab}}$ & $0.09^{\mathrm{b}}$ & 0.009 \\
\hline $20: 1$ & $0.28^{\mathrm{ab}}$ & $0.23^{\mathrm{a}}$ & $0.26^{\mathrm{ab}}$ & $0.29^{b}$ & 0.009 \\
\hline $20: 2 n-6$ & $0.13^{\mathrm{a}}$ & $0.15^{\mathrm{ab}}$ & $0.19^{\mathrm{b}}$ & $0.16^{\mathrm{ab}}$ & 0.008 \\
\hline $20: 3$ n-6 (DGLA) & $0.37^{\mathrm{AaB}}$ & $0.24^{\mathrm{Aa}}$ & $0.68^{\mathrm{Bb}}$ & $0.32^{\mathrm{Aa}}$ & 0.051 \\
\hline $20: 4$ n-6 (AA) & $1.73^{\mathrm{ABa}}$ & $1.02^{\mathrm{Aa}}$ & $3.20^{\mathrm{Bb}}$ & $1.52^{\mathrm{Aa}}$ & 0.242 \\
\hline $20: 5$ n-3 (EPA) & 0.24 & 0.32 & 0.34 & 0.23 & 0.021 \\
\hline 22:4 n-6 (Adrenic) & $0.29^{\mathrm{ab}}$ & $0.16^{\mathrm{a}}$ & $0.38^{\mathrm{b}}$ & $0.24^{\mathrm{ab}}$ & 0.029 \\
\hline $22: 5 n-3$ & $0.32^{\mathrm{Aa}}$ & $0.44^{\mathrm{AaB}}$ & $0.70^{\mathrm{Bb}}$ & $0.28^{\mathrm{Aa}}$ & 0.051 \\
\hline $22: 6 n-3$ & 0.18 & 0.23 & 0.21 & 0.15 & 0.018 \\
\hline Total UFA & $53.29^{\mathrm{AaB}}$ & $51.58^{\mathrm{Aa}}$ & $56.39^{\mathrm{Bb}}$ & $52.46^{\mathrm{Aa}}$ & 0.522 \\
\hline UFA : SFA & $1.38^{\mathrm{Aa}}$ & $1.32^{\mathrm{Aa}}$ & $1.57^{\mathrm{Bb}}$ & $1.36^{\text {Aa }}$ & 0.028 \\
\hline$n-6: n-3$ & $9.0^{\mathrm{Bbc}}$ & $3.60^{\mathrm{Aa}}$ & $6.74^{\mathrm{ABb}}$ & $9.24^{\mathrm{Bc}}$ & 0.582 \\
\hline $\mathrm{DFA}^{2}: \mathrm{OFA}^{3}$ & $2.97^{\mathrm{A}}$ & $2.92^{\mathrm{A}}$ & $3.46^{\mathrm{B}}$ & $2.91^{\mathrm{A}}$ & 0.068 \\
\hline Cholesterol level (mg/100 g MLD) & $59.53^{\mathrm{B}}$ & $50.05^{\mathrm{A}}$ & $46.45^{\mathrm{A}}$ & $51.98^{\mathrm{A}}$ & 1.281 \\
\hline
\end{tabular}

${ }^{1} \mathrm{C}$-control; L - with linseed; $\mathrm{RC}$ - with rapeseed oilcake; $\mathrm{RO}$ - with rape seed oil

2 desirable fatty acids - UFA + C 18:0 (dietary fatty acids having desirable neutral or hypocholesterolemic effect in human)

${ }^{3}$ undesirable fatty acids $-\mathrm{C} 14+\mathrm{C} 16$ (dietary fatty acids having undesirable hypercholesterolemic effect in human)

a,b,c $-\mathrm{P} \leq 0.05 ;{ }^{A, B, C}-\mathrm{P} \leq 0.01$

$\mathrm{SE}=\sqrt{\frac{\mathrm{s}^{2}}{\mathrm{n}}}$ 
M. longissimus dorsi of bulls fed the mixture with linseeds compared with the control or RO group was similar $(\mathrm{P}>0.05)$ but content of $\mathrm{C} 18: 3 \mathrm{n}-3$ acid was highest $(\mathrm{P}<0.01)$. The cholesterol level was highest in group $\mathrm{C}(\mathrm{P}<0.01)$, in the remaining groups it was similar but lowest in group $\mathrm{RC}$.

Data obtained for the physical and chemical properties of meat (Table 6) did not differ significantly between the groups.

TABLE 6

Chemical composition and physical and chemical properties of meat

\begin{tabular}{lccccc}
\hline \multirow{2}{*}{ Item } & \multicolumn{4}{c}{ Groups } & \multirow{2}{*}{ SE } \\
\cline { 2 - 5 } & $\mathrm{C}$ & $\mathrm{L}$ & $\mathrm{RC}$ & $\mathrm{RO}$ & \\
\hline Dry matter, \% & 26.24 & 27.59 & 26.51 & 27.33 & 0.28 \\
Crude protein, \% & 23.13 & 22.80 & 22.47 & 22.74 & 0.19 \\
Crude fat, \% & $1.72^{\mathrm{a}}$ & $3.67^{\mathrm{b}}$ & $2.34^{\mathrm{ab}}$ & $3.29^{\mathrm{b}}$ & 0.26 \\
Ash, \% & 1.14 & 1.04 & 1.09 & 1.08 & 0.03 \\
pH 24 h in $M$. longissimus dorsi & 5.46 & 5.47 & 5.47 & 5.48 & 0.01 \\
Water holding capacity, \% & 24.83 & 24.65 & 24.10 & 25.02 & 0.19 \\
Natural drip, \% & 0.68 & 0.91 & 0.43 & 0.69 & 0.09 \\
Thermal drip loss, \% & 33.15 & 32.79 & 17.98 & 34.04 & 0.61 \\
Total colouring substances, $\mathrm{mg} \mathrm{kg}^{-1}$ & $140.20^{\mathrm{b}}$ & $96.73^{\mathrm{a}}$ & $135.31^{\mathrm{b}}$ & $125.33^{\mathrm{ab}}$ & 6.44 \\
Colour lightness, \% & $14.24^{\mathrm{b}}$ & $14.66^{\mathrm{b}}$ & $13.51^{\mathrm{ab}}$ & $12.6^{\mathrm{a}}$ & 0.28 \\
Colour stability, \% & 3.66 & 3.46 & 2.80 & 5.39 & 0.58 \\
\hline
\end{tabular}

${ }^{1} \mathrm{C}$ - control; $\mathrm{L}$ - with ground linseed; $\mathrm{RC}$ - with rapeseed oil cake; $\mathrm{RO}$ - with rape seed oil a, b $-\mathrm{P} \leq 0.05$

$\mathrm{SE}=\sqrt{\frac{\mathrm{s}^{2}}{\mathrm{n}}}$

\section{DISCUSSION}

The high average daily body weight gains of animals in all groups obtained during the entire experimental period indicate that the feeding system used in this study resulted in the satisfactory formulation of the diets to cover the requirements of animals and rumen microorganisms. This is also corroborated by the growth rate and body size gains obtained in each particular weight compartment. The similar daily feed dry matter intake in all groups suggests that increase of fat up to $5 \%$ of dry matter in the diet in which about a half of fat was vegetable oil from ground linseed, rapeseed oil cake or rape seed oil does not alter feed intake and body gain. Rule et al. (1994) feeding bulls with diets based on maize silage with soyabean or rape seed containing from 4.7 to $11.2 \%$ fat in dry matter of ration found a slight tendency towards decreased feed intake and body weight gain only 
at the highest level of fat in the diet. The reason for some differences in daily intake of crude protein, PDI and energy (UFV) and efficiency of PDI and UFV kg-1 of body gain in the present experiment could be that the experimental diets were formulated with the intention to introduce a maximum of fat using feed ingredients of different fat and protein contents.

The higher ratio of UFA:SFA in $M$. longissimus dorsi of animals on rapeseed oil cake than on the other fat sources could be caused by limited biohydrogenation of UFA in the rumen because of the better protection of this fat from microbial activity. This suggestion is supported by the higher content of $\mathrm{C} 18: 2 \mathrm{n}-6(\mathrm{P}<0.01)$ in $M$. longissimus dorsi than in the remaining groups. Jilg et al. (1988), Murphy et al. (1990), Chang et al. (1991) and Rule et al. (1994) reported that the physical form of feed may influence protection of fat from biohydrogenation in the rumen. It can be presumed that rapeseed oil cake fat was better protected from biohydrogenation than that of linseed meal, leading to a decrease of $\mathrm{C} 18: 2 \mathrm{n}-6 \mathrm{in} \mathrm{M}$. longissimus dorsi.

Animals on the diet with rape seed oil indeed consumed similar amounts of C 18:2 $\mathrm{n}-6$ as animals in groups $\mathrm{L}$ and $\mathrm{RC}\left(37 \mathrm{~g} \mathrm{~d}^{-1}\right)$ but the concentration of this acid in $M$. longissimus dorsi was clearly lower, suggesting a higher degree of biohydrogenation in the rumen. Higher biohydrogenation of UFA in the case of feeding rape seed oil with the diet also clearly suggests a lower level of conjugated linoleic acid and linolenic (C 18:3 n-3) acid than in the group RC.

The higher contents of dihomo- $\gamma$-linoleic acid 20:3n-6, arachidonoic acid 20:4 n-6, adrenic acid 22:4 n-6 and docosapentaenoic acid 22:5 n-3 in M. longissimus dorsi of animals in group $\mathrm{RC}$ than in remaining groups $(\mathrm{P}<0.01$ or 0.05$)$ could be a result of desaturation and elongation occurring in the tissue (Jenkins and Kramer, 1990; Nettleton, 1991; Chang et al., 1992). Significantly higher concentration of C 18:3 n-3 in $M$. longissimus dorsi of animals fed the diet with ground linseed, compared with the remaining groups, could be explained by higher intake of this acid in this group ( $\left.106 \mathrm{~g} \mathrm{day}^{-1}\right)$ than in groups L and RO $\left(17 \mathrm{~g} \mathrm{day}^{-1}\right)$. However, it can not be excluded that $\mathrm{C} 18: 3 \mathrm{n}-3$ acid of linseed origin enriched the conjugated C 18:2 (CLA) pool in lipids of $M$. longissimus dorsi. Indeed, processes of hydrogenation do not cover CLA (Harfoot and Hazlewood, 1988), however during hydrogenation of linolenic acid in the rumen $\mathrm{C} 18: 1$ trans- 11 acid is produced which can be transformed into CLA endogenously involving $\Delta-9$ desaturase (Griinari et al., 1997). The significantly higher content of conjugated C 18:2 (CLA) in the $M$. longissimus dorsi in group RC than in groups $\mathrm{C}$ and $\mathrm{RO}$ could probably be explained by slower biohydrogenation of isomer C 18:2 n-6 in the rumen. However it can not be excluded that the proportion of fatty acids in the fat of $M$. longissimus dorsi in respective groups was affected by different proportion of maize silage fat, which amounted to about $60 \%$ in the control group but only $30-36 \%$ of total dietary fat in experimental diets. These processes could be the 
reason that differences between the groups in the concentration of majority of fatty acids did not reach statistical significance, however, individual fatty acid contents in maize silage fat in this experiment were not measured.

The ratio of $n-6: n-3$ in fat of $M$. longissimus dorsi was in the range from 3.6:1 to $9.2: 1$ and was close to values from $3: 1$ to $9: 1$ in majority of body tissues reported by Horrobin (1990). A marked decrease of the $n-6: n-3$ ratio in meat of bulls fed linseed suggests that it has a higher dietetic value because of the beneficial antisclerotic properties of n-3 family acids (Brisson, 1986). They could also cause a decrease the level of total cholesterol in $M$. longissimus dorsi animals of this (L) group compared with the control group. On the other hand, the lower content of cholesterol in the meat of RC group animals than in the control group could probably be related to the higher content of unsaturated fatty acids and higher ratio of hypocholesterolemic to hypercholesterolemic acids.

\section{CONCLUSIONS}

Summarizing the results of the experiment, it can be concluded that fattening bulls from 184 to $530 \mathrm{~kg}$ body weight fed rations formulated according to IZINRA standards (1997) consisting of (DM basis) $56 \%$ maize silage and $44 \%$ concentrate supplemented with vegetable oils, provided an average daily body weight gain of about $1.35 \mathrm{~kg}$. The fat content increased to about $5 \%$ in dry matter of the diet with about $50 \%$ fat of linseed or rapeseed oil cake, enriched the lipids of meat in essential, unsaturated fatty acids and conjugated linoleic acid and decreased cholesterol level, which was particularly marked when feeding the diet supplemented with rapeseed oil cake.

\section{REFERENCES}

AOAC, 1990. Official Methods of Analysis. 15th Edition. Association of Official Analytical Chemists, Arlington, VA

Brisson G.J., 1986. Dietary fat and human heath. In: W. Haresigh, D.J.A. Cole (Editors). Recent Advances in Animal Nutrition. Butterworts, Boston, pp. 3.24

Calder P.C., 1997. n-3 Polyunsaturated fatty acids and cytokine production in health and disease. Ann. Nutr. Metab. 41, 203-234

Chang J.H.P., Lunt D.K., Smith S.B., 1992. Fatty acid composition and fatty acid clongase and stearoyl-CoA desaturase activities in tissues of steers fed high oleate sunflower seed. J. Nutr. $122,2074-2080$

Chang J.H.P., Sturdivant C.A., Greene L.W., Lunt D.K., Smith S.B., 1991. Fatty acid absorption of cattle fed diets containing high-oleate sunflower seed. J. Anim. Sci. 69, Suppl.1, 547-548 (Abstr.) 
Givens DE.I., Cottril B.R., Davies M., Lce P.A., Mansbridge R.J., Moss A. R., 2000. Sources of 3-n polyunsaturated fatty acids additional to fish oil for livestock diet - a review. Nutr. Abstr. Rev., Ser. B 70, 1-19

Griinari J.M., Chouinard P.Y., Bauman D.E., 1997. Trans fatty acid hypothesis of milk fat depression revised. Proceedings of Cornell Nutrition Conference for Feed Manufactures, Rochester, NY, Cornell University, Ithaca, NY, pp. 208-216

Grimble R.F., 1998. Modulation of inflamatory aspect of immune functions by nutrients. Nutr. Res. $18,1297-1317$

Harfoot C.G., Hazlewood G.P., 1988. Lipid metabolism in the rumen. In: P.N., Hobson (Editor). The Rumen Microbial Ecosystem. Elsevier Sci. Publ., Amsterdam (The Netherlands), pp. 285-322

Hoffmann D.R., Birch E.E., Birch D.G., Uauy R.D., 1993. Effect of supplementation with $\omega-3$ longchain polyunsaturated fatty acids for retinal and cortical development in premature infants. Amer. J. Clin. Nutr. 57, Suppl. 5, 807S-812S

Horrobin D.F., 1990. $\gamma$-Linolenic acid: An intermediate in essential fatty acid metabolism, with potential as an ethical pharmaceutical and as food. Rev. Contemp. Pharmacother. 1, 1-45

IZ-INRA, 1997. Standards for Cattle, Sheep and Goat Nutrition (in Polish). Research Institute of Animal Production, Kraków (Poland)

Jenkins T.C., Kramer J.K.G., 1990. Effects of dietary corn oil and fish oil concentrate on lipid composition of calf tissues. J. Dairy Sci. 73, 2940-2951

Jilg T., Aiple K.P., Steingass H., 1988. Fettstoffweschel und Wirkungen von Futterfetten beim Wiederkäuer. Übers. Tierernähr. 16, 159-162

Kenneliy J.J., 1996. The fatty acid composition of milk fat as influenced by feeding oilseeds. Anim. Feed Sci. Tech. 60, 137-152

Maes M., 1999. Major depression and activation of the inflammatory response system. Adv. Exp. Med. Biol. 461, 25-46

Murphy J.J, McNell, G.P., Connolly J.F., Glesson P.A., 1990. Effect on cow performance and milk fat composition of including of full fat soya bean and rape seed in the concentrate mixture for lactating dairy cows. J. Dairy Res. 57, 295-306

Nettleton J.A., 1991. $\omega$-Fatty acids: Comparison of plant and seafood sources in human nutrition. J. Amer. Diet. Assn. 91, 331-337

Rule D.C., Busboom J.R., Kercher C.J., 1994. Effect of dietary canola on fatty acid composition of bovine adipose tissue, muscle, kidney and liver. J. Anim. Sci. 72, 2735-2744

Scollan N.D., Fisher W.J., Davies D.W.R., Fisher A.V., Enser M., Wood J.D., 1997. Manipulating the fatty acid composition of muscle in beef cattle. Proc. Brit. Soc. Anim. Sci, Scarborough, p. 20

Sheard N.F., 1998. Fish consumption and risk of sudden cardiac death. Nutr. Rev. 56, 177-179

Simopoulos A.P., 1991. $\omega-3$ fatty acid in health and disease and in growth and development. Amer. J. Clin. Nutr. 54, 438-463

Stasiniewicz T., Strzetelski J.A., Kowalczyk J., Osięgłowski S., Pustkowiak H., 2000. Performance and meat quality of fattening bulls fed diets with rapesced oil cake or linseed. J. Anim. Feed Sci. 9, 271-282

Strzetelski J.A., Krawczyk K., Kowalczyk J., Stasiniewicz T., Osięgłowski S., Lipiarska E., 1998. Performance and body fat composition of fattening bulls fed diets with evening primrose (Oenothera paradoxa) oil cake. J. Anim. Feed Sci. 7, 261-271 


\section{STRESZCZENIE}

Opas buhajków żywionych kiszonką z kukurydzy i mieszankami pasz treściwych z dodatkiem tluszczów roślinnych

W doświadczeniu przeprowadzonym na 44 buhajkach rasy cb (4 grupy po 11), od średniej masy ciała $184 \mathrm{~kg}$ do $530 \mathrm{~kg}$, badano efektywność opasu i jakoość mięsa. Po sześć buhajków z każdej grupy ubito na zakończenie doświadczenia. Dawkę podstawową dla grupy kontrolnej stanowiła kiszonka z kukurydzy oraz granulowana mieszanka treściwa. W grupach doświadczalnych do mieszanki treściwej dodawano śrutowane nasiona lnu, makuch rzepakowy lub olej rzepakowy, jako źródło tłuszczu. Skarmiane dawki były zbilansowane pod względem energetyczno:białkowym wedhug norm

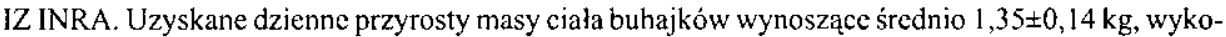
rzystanie suchej masy skarmianych pasz, $5,4 \pm 0,07 \mathrm{~kg} / \mathrm{kg}$ przyrostu, oraz właściwości fizyko-chemiczne mięsa nie różniły siç istotnic pomiędzy grupami. W tłuszczu mięśnia najdłuższego grzbietu buhajków karmionych dawką $z$ dodatkiem makuchu rzepakowego stwierdzono wį̧kszą zawartość nicnasyconych kwasów tłuszczowych o liczbie 18,20 i 22 atomów węgla w cząsteczce oraz wyższy stosunek kwasów hipo- do hipercholesteromicznych niż w pozostałych grupach. Mięso buhajków z grup otrzymujących pasze z dodatkiem tłuszczów roślinnych, a szczególnie makuchu rzepakowcgo, zawierało mniej cholesterolu w tłuszczu miçsa niż w grupie kontrolnej. 